\title{
Biological Activity of Pomegranate Extract Against Phytopathogenic Fungi From Strawberry
}

\author{
Jéssica dos Santos Lima (III), Diego Renan Sobreiro Falcão Paim \\ (II), Aline Luiza Machado Carlos (III), Regina Isabel Nogueira (I), \\ Otniel Freitas-Silva (I)
}

(I) EMBRAPA - EMBRAPA Food Technology (Av. das Américas, 29501, Rio de Janeiro, RJ, CEP 23020-470), (II) UFRRJ - Universidade Federal Rural do Rio de Janeiro (BR 465, Km 7, Campus Universitário - Seropédica, Rio de Janeiro, RJ, 23851-970), (III) UEZO - Centro Universitário Estadual da Zona Oeste (Av. Manuel Caldeira de Alvarenga, 1203 - Rio de Janeiro, RJ, 23070-200)

\section{Resumo}

The phenolic compounds are found in many species of plants. The classes of these compounds have mostly antioxidant action, fighting to free radicals and in some species have been demonstrated antimicrobial activity becoming sources of promoting beneficial to human health. The pomegranate is a source of these compounds and therefore has been studied excelling its composition of anthocyanins, phenolic acids and tannins, among them, the punicalagin. This work aimed to evaluate in vitro antifungal activity of an aqueous extract of pomegranate peel. This extract was tested against post harvested fungi from strawberries. For this purpose increasing concentrations of pomegranate extract $(0,2.5,25$ and 100 $\mathrm{mg} / \mathrm{mL}$ ) was added to the culture medium Potato Dextrose Agar (PDA). The inoculum was composed by discs with mycelium $(0.5 \mathrm{~cm}$ in diameter $)$ from each fungus (Botrytis cinerea, Colletotrichum gloeosporioides and Pilidium concavum). The disc was inserted in Petri dishes with PDA and incubated at $25{ }^{\circ} \mathrm{C}$ for 10 days. The diameter of the colonies was measured daily and compared to the control plates (without pomegranate extract). The results showed the ability of the pomegranate extract in controlling the mycelial growth of fungi. The best result was observed in Colletotrichum gloeosporioides. For this species the growing percentage values were 3.67 $\%(2.5 \mathrm{mg} / \mathrm{mL}), 11.94 \%(25 \mathrm{mg} / \mathrm{mL})$ and $42.25 \%(100 \mathrm{mg} / \mathrm{mL})$, respectively. For others fungi also the concentration of $100 \mathrm{mg} / \mathrm{mL}$ reduced

\footnotetext{
Referência:

Jéssica dos Santos Lima, Diego Renan Sobreiro Falcão Paim, Aline Luiza Machado Carlos, Regina Isabel Nogueira, Otniel FREITAS-SILVA.Biological Activity of Pomegranate Extract Against Phytopathogenic Fungi From Strawberry. In: Anais do $12^{\circ}$ Congresso Latinoamericano de Microbiologia e Higiene de Alimentos - MICROAL 2014 [= Blucher Food Science Proceedings, num.1, vol.1]. São Paulo: Editora Blucher, 2014. DOI $10.5151 /$ foodsci-microal-054
} 
fungal growing of Botrytis cinerea (41.2\%) and Pilidium concavum (2.7\%). This study showed the potential of pomegranate extracts controlling post harvested pathogens from strawberries. Due the antifungal properties of the pomegranate peels its open an opportunity to reduce this agro-industrial waste with potential applications in agriculture.

Palavras-Chave: fungi, phenolics, pomegranate extract, postharvest diseases Agência de Fomento: Fundação de Amparo à Pesquisa do Estado do Rio de Janeiro (FAPERJ) 